\title{
ПЕДАГОГІЧНІ УМОВИ ФОРМУВАННЯ ГЕНДЕРНОЇ КУЛЬТУРИ УЧНІВ 10-11 КЛАСІВ ЗАСОБАМИ УКРАЇНСЬКОЇ ЛІТЕРАТУРИ
}

УДК: 373.5.016:821.161.2]:316.346.2

\section{Бутурлим T. I.}

Кандидат психологічних наук, учитель вищої категорії, Ніжинський обласний педагогічний ліиеей Чернігівської обласної ради, м. Ніжин (Украӥна)

\begin{abstract}
Анотація. У статті визначено педагогічні умови формування гендерної культури старшокласників у процесі вивчення украӥнської літератури: мотивування учнів до зіставлення власних тендерних цінностей та гендерних цінностей художніх персонажів; підвищення професійної компетентності вчителів щодо формування тендерної культури старшокласників; використання інтерактивних методів і форм гендерного виховання.
\end{abstract}

Ключові слова: гендерне виховання, гендерна культура, украӥнська література, тендерні цінності, гендерна компетентність, інтерактивні психолого-педагогічні вправи.

Постановка проблеми. Конструювання моделі формування гендерної культури старшокласників у процесі вивчення української літератури зумовлює необхідність у визначенні шляхів удосконалення взаємин між чоловіком та жінкою. Аналіз праць із гендерології показав, що більшість наукових розвідок на вищезазначену тему носять теоретичноописовий, узагальнюючий характер.

Аналіз останніх досліджень і публікацій. Практичні знахідки актуалізувалися в історії гендерної педагогіки, психології, філософії, методиці навчання й виховання лише в останнє десятиріччя. Серед них дисертаційні дослідження (А. Аніщенко, С. Вихор, О. Вiлкова, Т. Власова, Т. Говорун, Н. Городнова,
I. Жеребкіна, О. Камінська, Н. Коростильова, Т. Кубриченко, Н. Левчик, Т. Лук'яненко, Л. Мозгова, І. Мунтян, П. Терзі, Т. Ткаченко, Л. Харченко, Л. Яценко, С. Яшник та ін.); навчально-методична література, словники, збірки матеріалів всеукраїнських та міжнародних конференцій, публікації в періодичних виданнях.

Незважаючи на підвищений інтерес науковців до гендерного виховання, проблема педагогічних умов формування гендерної культури старшокласників у процесі вивчення української літератури залишається лакуною в гендерології. Тому метою статті $\epsilon$ визначення педагогічних умов формування гендерної культури старшокласників у процесі вивчення 
української літератури.

Виклад основного матеріалу і результатів дослідження. У контексті реалізації технології формування гендерної культури старшокласників у процесі вивчення української літератури [1] педагогічними умовами, на нашу думку, є комплекс педагогічних заходів, спрямованих на підвищення рівня розвитку когнітивного, емочійно-ијіннісного, поведінкового компонентів тендерної культури учнів у контексті вивчення украӥнської літератури.

Психолого-педагогічний досвід, теоретичний аналіз літератури 3 гендерології, спостереження за поведінкою учнів, аналіз їх висловлювань на гендерну тематику показують, що основними шляхами реалізації моделі формування гендерної культури старшокласників у процесі вивчення української літератури $є$ мотивування учнів до зіставлення власних тендерних иінностей та тендерних иінностей художніх персонажів; підвищення професійної компетентності вчителів щодо формування гендерної культури старшокласників; використання інтерактивних методів і форм тендерного виховання. Вищезазначені педагогічні умови грунтуються на принципах виховання, визначених авторським колективом «Програми виховання дітей та учнівської молоді в Україні» [2], а саме: принципі національної спрямованості виховання, принципі культуровідповідності, принципі гуманізації, принципі суб'єкт-суб'єктної взаємодії, принципі цілісності, акмеологічному принципі, принципі особистісної орієнтації, принципі життєвої самодіяльності, принципі полікультурності, принципі технологізації, принципі соціальної відповідності, принципі превентивності.

Основний зміст першої педагогічної умови - мотивування учнів до зіставлення власних гендерних цінностей та гендерних цінностей художніх персонажів - полягає у формуванні в старшокласників уміння співвідносити гендерну культуру літературних героїв із власним гендерним світоглядом, гендерною позицією, гендерними ролями, здатністю протистояти патріархатматріархатним стереотипам, налагоджувати діалогічні гендерні взаємини; уміння переосмислювати особистий гендерний досвід на основі усвідомлення гендерних цінностей персонажів жіночої та чоловічої статі; потреби в гендерному самовдосконаленні; здатності конструювати ефективний план дій на шляху до віднайдення гендерної гармонії тощо. Розроблена технологія спрямована на усвідомлення важливості гармонії у взаєминах статей, зокрема взаємного кохання, щирості, вірності, взаємодопомоги, взаєморозуміння, спільного вирішення життєвих проблем, взаємопідтримки на шляху до самоактуалізації обох партнерів гендерної комунікації. Характер і ступінь розвитку гендерного досвіду старшокласників залежить від уміння вчителя української літератури допомогти їм побачити типові помилки гендерних взаємин персонажів, орієнтовну 
схему побудови гармонійної сім'ї та змоделювати власну систему гендерних цінностей.

Формування когнітивної складової гендерної культури передбачає засвоєння гендерної теорії та усвідомлення старшокласниками рівня власної гендерної культури, місця в системі гендерних взаємин. В урочний час підвищення інтересу до проблеми рівності статей і засвоєння старшокласниками ґендерних знань доцільно здійснювати на всіх етапах занять української літератури. На етапах актуалізації опорних знань, умінь і навичок та мотивації навчальної діяльності важ ливим є вступне слово вчителя. Н-д: «Кожен творить життя таким, яким він його бачить. I саме від наших рішень залежить траєкторія екзистенції. Сьогодні на уроці ми побачимо, який життєвий шлях обирають для себе чоловічі й жіночі персонажі роману Панаса Мирного та Івана Білика «Хіба ревуть воли, як ясла повні?», що завадило їм побудувати гармонійні взаємини». Підвищенню інтересу старшокласників до гендерного аспекту твору та власної гендерної культури сприяють проблемні запитання. Нд: «Внутрішня й міжособистісна гармонія особистості в більшості випадків визначається тим, як до нас ставляться інші: чи люблять, поважають чи виражають незадоволення, психічно/фізично пригнічують. Як правильно побудувати своє життя, щоб нас оточувала лише любов, взаєморозуміння, щирість?» Також у процесі формування когнітивної складової гендерної культури старшокласників важливим
$€$ апелювання до гендерного свіпогляду учнів (н-д, «Підніміть картку із зображенням чоловіка, жінки чи представників обох статей відповідно до ваших гендерних поглядів»); установлення зв'язку з раніше вивченим матеріалом (н-д, «У яких художніх текстах українських та зарубіжних письменників змальовується рівність/нерівність між чоловіком та жінкою? Які особливості зображення гендерної картини світу цих творів?»); повторення вивченого (н-д, гендерної термінології, сутності гендерної інтерпретації художнього тексту, гендерної картини світу вивчених текстів); демонстрація відеоколажу відомих мелодрам, що презентує модель справжнього кохання, толерантності, гендерної справедливості; аналіз висловлювань про кохання видат них філософів, психологів тощо.

\section{Удосконаленню когнітивного компоне-} нта ґендерної культури старшокласників сприяють навчально-виховні завдання на еmani засвоєння нових знань, формування практичних умінь, навичок та узагальнення й систематизації вивченого. Усі елемент и гендерної інт ерпретації художнього тексту (аналіз гендерного світогляду митця в тексті; характеристика гендерної картини світу (дисгармонійної (патріархатної/матріархатної), гармонійної (гендерної рівності)); зіставлення різних поглядів героїв на місце чоловіка та жінки в сімейній, суспільній, політичній, виробничій сферах; аналіз типів чоловічих і жіночих світів, особливостей їх взаємин; прослідковуван- 
ня еволюції міжстатевих відносин; дослідження ознак гендерної гармонії, рівності чи нерівності, насильства; характеристика гендерних ролей, статусу статей; визначення причин руйнування гендерних цінностей; моделювання шляхів формування андрогінної родини героїв; зіставлення гендерного світогляду героїв із поглядами на взаємини чоловіка та жінки інших художніх персонажів; побудова узагальнюючих схем, графіків, таблиць) супроводжуються гендерним вихованням. Тобто, здійснюючи інтерпретацію гендерних взаємин художніх персонажів, рівня їх гендерної культури, учитель спонукає старшокласників до переосмислення й усвідомлення особливостей розвитку власних гендерних якостей, знань, умінь, цінностей, учинків по відношенню до особи протилежної статі. Так, модель гендерної культури художніх образів умовно проектується на свідомість старшокласників, у результаті чого вони можуть прийняти іiі, удосконалити з метою практичного застосування в реальному житті, або не прийняти, усвідомлюючи неефективність та руйнівний характер дисгармонійного поєднання чоловічих і жіночих якостей, гендерної нерівності, насилля. Важливу роль відіграють евристичні бесіди, спрямовані на розв'язання навчальних завдань та питань гендерного розвитку особистості учнів. Н-д: «Чим зумовлена другорядна позиція Галі, Христі, Мотрі в патріархатному суспільстві («Хіба ревуть воли, як ясла повні?» Панаса Мирного та Івана Бі- лика)? Як ви оцінюєте ситуацію взаємин статей на сучасному етапі життя?»). Не менш важливу роль у формуванні гендерної культури старшокласників відіграють проблемні завдання. Н-д: на основі аналізу гендерних ролей художніх образів визначити, до якого типу жінки належить Марія, які гендерні ролі характеризують Гната як фемінного, а Корнія - як маскулінного, оцінити рівень їх гендерної культури («Марія» У. Самчука), проаналізувати власні чоловічі й жіночі якості, визначити, які з них сприяють побудові толерантних взаємин з особою протилежної статі, а які перешкоджають. Творча робота в процесі вивчення української літератури не лише актуалізує пізнавальну діяльність учнів, а й розвиває образне уявлення моделі гендерних взаємин у майбутній сім'ї. Прикладом таких завдань $є$ асоціативне представлення взаємин Івана та Марічки, Івана та Палагни («Тіні забутих предків» М. Коцюбинського), аналіз ступеня гармонійності у власних взаєминах 3 особою протилежної статі.

Розвитку когнітивного компонента гендерної культури старшокласників сприяють домашні завдання. Н-д: дати письмову відповідь на запитання «Яким (-ою) ви уявляєте свого (-ю) майбутнього (-ю) супутника (-цю) життя? Окресліть модель бажаних гендерних взаємин».

Отже, формування інтересу до ідеї рівності чоловіка та жінки, усвідомлення власного місця в системі гендерних взаємин здійс- 
нюється через художній текст. Учитель української літератури допомагає старшокласникам транслювати гендерну картину світу художнього тексту на свідомість учнів із метою формування неприйняття інтолерантної позиції персонажів до особи протилежної статі та розцінювання андрогінних чоловіка й жінку як зразкових.

Формування емоційно-ціннісної складової гендерної культури старшокласників засобами української літератури передбає конструювання таких гендерних цінностей, що визначатимуть конструктивний характер взаємин $з$ особою протилежної статі: рівність між чоловіком та жінкою, толерантність, справедливість, співробітництво. Усвідомивши рівень розвитку гендерної культури, учні мають змоделювати у власній свідомості образ гармонійної особистості як бажаного результату гендерного виховання та самовиховання. Оскільки програма з української літератури презентує лише незначну кількість художніх творів із гармонійною моделлю гендерних взаємин, важливо орієнтувати учнів на продукування гендерних цінностей шляхом усвідомлення конструктивного досвіду андрогінних персонажів (н-д, Марічки й Іванка («Тіні забутих предків» М. Коцюбинського), Наталки та Григорія («Тигролови» Івана Багряного)) i розуміння типових помилок гендерно нетолерантних персонажів (н-д, Чіпки й Галі («Хіба ревуть воли, як ясла повні» Панаса Мирного та Івана Білика), Мавки й Лукаша («Лісова пісня» Лесі
Українки)). Інтерпретація зображеної у творах гендерної нерівності не має розвинути в старшокласників потребу наслідувати аморальність, бездуховність, байдужість до почуттів інших, гіпермаскулінність чи гіперфемінність, схильність до гендерного насильства. Учитель повинен виховати в учнів неприйняття деструктивних явищ у взаєминах між чоловіком та жінкою, потребу вдосконалити гендерну культуру.

Основними шляхами формування практичних умінь і навичок $є$ завдання, що потребують аналітичного мислення, актуалізації творчих здібностей. Це евристичні запипання (н-д, Чому Лукаш і Килина («Лісова пісня» Лесі Українки), Іван і Палагна («Тіні забутих предків» М. Коцюбинського) не змогли досягти гендерної гармонії? Як ви поводите себе в ситуації гендерної нерівності? Яким чином вирішуєте непорозуміння з особою протилежної статі, попереджуєте акти насильства?) та проблемні завдання (н-д, змоделювати варіант шлюбу без насильства («Перехресні стежки» I. Франка), розіграти уявну картинку неприйняття гендерного насилля в результаті раціональних активних дій).

Таким чином, проведення паралелі між гендерними цінностями художніх персонажів та гендерними цінностями старшокласників сприяє усвідомленню учнями рівня розвитку гендерної культури, розвитку потреби в самовдосконаленні, конструюванню власної гендерної позиції, бажаного образу взаємин статей, 
реалізації ідеї рівності статей.

Друга педагогічна умова - підвищення професійної компетентності вчителів щодо формування гендерної культури старшокласників (складова гендерної культури вчителя, здатність ефективно застосувати сукупність гендерних знань, гендерних цінностей, гендерних умінь i навичок у навчальновиховному процесі з метою формування високого рівня гендерної культури учнів). Як показує психолого-педагогічний досвід, ефективний розвиток ґендерної компетентності визначається високою обізнаністю вчителя 3 технологією формування гендерної культури старшокласників засобами української літератури, умінням організувати конструктивне дешифрування художнього тексту, виховати конструктивні гендерні якості особистості. Значну роль у формуванні чи корекції гендерних знань відіграє тендерна просвіта, основною метою якої $є$ формування цілісності й об'єктивності знань щодо особливостей гендерного виховання, розуміння змісту категоріального апарату гендерної педагогіки, структури й етапів здійснення технології формування гендерної культури старшокласників. Вона має здійснюватися відповідно до принципів доступності, наочності, діалогізму, активності й самостійності, систематичності, свідомості й міцності знань, зв'язку із життям. У роботі з учителями щодо підвищення рівня гендерної компетентності доцільним є використання таких меподів: інтерактивна лекція, евристична бесіда, дискусія, гра, метод вправ, групова, індивідуальна, колективна, самостійна робота, робота в парах, дослідницькі завдання, розв'язання проблемних ситуацій, демонстрація, приклад високого рівня гендерної культури видатних людей, художніх персонажів, переконання щодо розвитку паритетного ставлення до чоловіка та жінки, метод прогнозування гармонійного гендерного розвитку, заохочення, рефлексія.

Тренер у процесі формування гендерних знань вчителів має враховувати їх світоглядну позицію щодо місця чоловіка й жінки в суспільстві. У випадку неприйняття вчителями ідеї гендерної рівності важливо не нав'язувати бажані гендерні цінності, а спонукати до усвідомлення ними важливості гендерної гармонії та деструктивності нерівності у взаєминах осіб протилежної статі. Обсяг теоретичних знань, необхідних для здійснення гендерного виховання, має бути недостатньо великим, систематичним і лаконічним, оскільки гендерна концепція є лише засобом формування гендерної культури старшокласників, а не визначальною категорією в процесі виховання. Тому доцільно обмежитися поглибленням знань учителів про гендер, взаємини чоловіка та жінки в історії розвитку суспільства, гендерну педагогіку, технологію формування гендерної культури. Педагоги мають зрозуміти зміст ключової гендерної термінологіӥ: гендер, гендерна проблематика, гендерні ролі, гендерний світогляд, гендерна свідомість, гендерна 
ідентичність, гендерна картина світу, гендерні знання, гендерні стереотипи, фемінність, маскулінність, андрогінність, гендерна гнучкість, гендерна чутливість, гендерна гармонія/дисгармонія, гендерна рівність/нерівність, гендерне насилля, гендерна культура, виховання гендерної культури старшокласників засобами української літератури.

Не менш значимим $є$ формування практичних тендерних умінь у процесі вивчення української літератури, зокрема аналізувати будь-який гендерно чутливий навчальний матеріал у контексті гендерної концепції та застосовувати сформований конструктивний досвід у процесі гендерної соціалізації.

Важливу роль у формуванні гендерної культури старшокласників відіграє гендерна позиція вчителя. Педагог, який здійснює гендерне виховання, має демонструвати конструктивний зразок гендерної культури, тобто розвивати в собі якості гендерно коректної особистості.

Таким чином, результат гендерного виховання значною мірою залежить від гендерної компетентності учасників навчальновиховного процесу, зокрема від грунтовності й цілісності гендерних знань, ступеня усвідомлення сутності гендерного підходу, шляхів вивчення гендерної теорії, уміння здійснювати гендерну інтерпретацію тексту, здатності встановити діалогічний зв'язок між гендерною картиною світу персонажів і старшокласників, готовності учнів трансформувати сте- реотипну гендерну свідомість чи вдосконалити власну гендерну культуру, гендерної коректності вчителя, урахування психологічних особливостей старшокласників.

Важливою умовою виховання гендерної культури старшокласників у процесі осмислення текстів $є$ використання інтерактивних методів і форм гендерного виховання, що стимулюють творчість, самостійне й критичне мислення. Виконання будь-яких завдань, спрямованих на формування гендерної культури старшокласників, має бути зорієнтованим на гендерне «Я» старшокласників, супроводжуватися резюмуванням учнями особливостей розвитку власної гендерної культури та проектуванням можливих шляхів іiі вдосконалення. Так, аналіз типів жіночочоловічого світу тексту, характеру їх взаємин, моделювання адекватно правильної гендерної художньої ситуації у формі гри, nсихологічних вправ, асоціативних малюнків, літературних колажів, комп'ютерних презентацій із застосуванням узагальнюючих схем, таблиць, графіків, діаграм, групової роботи, роботи в парах та ін., як показують педагогічні спостереження, бесіди з учителями, результати педагогічного дослідження, активізують пізнавальну діяльність старшокласників, розвивають креативні здібності, акумулюють систему гендерних знань, умінь, навичок, формують високий ступінь гендерної самосвідомості, відповідальне ставлення до можливих наслідків продукування власної ген- 
дерної культури. Створені нами психологопедагогічні вправи зорієнтовані на те, щоб учні якнайбільше були задіяні в інтелектуальноруховій діяльності, рефлексії власної гендерної поведінки та розвитку практичних умінь конструктивних взаємин 3 особою протилежної статі. Н-д, розвитку адекватної самооцінки щодо гендерних взаємин сприяє вправа «Чорні й червоні серця». Кожен учень має оцінити власне гендерне «Я» 3 допомогою паперових сердець (червоним, якщо вважає себе гендерно коректним, чорним - гендерно некоректним), указуючи рівень розвитку гендерної культури, на основі чого створюється узагальнюючий гендерний портрет мікрогрупи. Потім старшокласники визначають тип гендерної поведінки художніх персонажів: розподіляють маленькі червоні/чорні сердечка між двома склянками $з$ написами «гендерно коректні персонажі» та «гендерно некоректні персонажі». Наприкінці учні мають узагальнити риси гендерно коректних та некоректних художніх образів і визначити, чию поведінку хотіли б наслідувати/не повторювати в реальному житті. Після гендерної інтерпретації поведінки персонажів старшокласники повторно оцінюють власне «Я» 3 допомогою паперових сердечок. Засобом формування позитивного сприйняття образу майбутньої сім'ї є релаксаиія: «Закрийте очі. Зробіть глибокий вдих, видих. Уявіть, що ви, проснувшись одного дня, відчули, як усе довкола змінилось: люди усміхнені, привітні, хочеться жити, творити, розвива- тися. Аж ось відчинилися двері - увійшов ваш чоловік (для дівчат) / дружина (для хлопців). Серце відразу почало радісно пульсувати, адже побачили близьку людину, ту, із якою хочеться провести решту свого життя. Запитавши про те, як він/вона провів (провела) день, як себе почуває, починаєте разом готувати вечерю та прибирати в будинку. Після виконання домашньої роботи разом ідете до спортивної зали, а згодом - у танцювальний клуб. Наповнені позитивними емоціями, удома обмінюєтеся враженнями, плануєте завтрашній день, обговорюєте, як реалізувати творчі ідеї, що виникли впродовж дня. Розумієте, що саме таким ви бали своє подружнє життя 5-10 р. тому. Кажете: «Я щаслива (-ий)! Рівність прав та обов'язків - запорука гармонійної сім'ї! Сподіваюся, що мої діти також будуватимуть родину на засадах любові, взаємоповаги, взаємодопомоги, рівності, свободи!»

Висновки. Отже, комплексна реалізація педагогічних умов формування гендерної культури старшокласників спонукатиме старшокласників до пізнання, удосконалення гендерної культури, реалізації гендерних знань, умінь, цінностей у повсякденному житті. Застосування технології формування гендерної культури старшокласників засобами української літератури є можливим в урочний та позаурочний час, зокрема в процесі інтерпретації гендерного аспекту художніх текстів, на уроках узагальнення й систематизації вивченого матеріалу, консультаціях, спецкур- 
cax, предметних тижнях, конференціях, семінарах, тренінгах, у контексті написання наукових робіт, створення творчих проектів тощо. Цілісність організації процесу гендерного виховання засобами української літератури допоможе учням у реальному житті адекватно оцінити гендерний світ, віднайти власне місце в ньому, генерувати гендерні знання 3 метою моделювання шляхів гармонійного співіснування $з$ особою протилежної статі в реальному житті.

\section{Перспективи}

подальших

дослі-

джень. Подальші дослідження будуть спрямовані на формування гендерної культури вчителів та батьків.

\section{Перелік використаних джерел:}

1. Бутурлим Т. I. Формування гендерної культ ури ст аршокласників у процесі вивчення української літератури : дис. на здобуття наук. ступеня канд. пед. наук : спец. 13.00.07 / Ін-т проблем виховання НАПН України. - Київ, 2013. - 400 с.

2. Програма виховання діт ей т а учнівської молоді в Україні [Електронний ресурс] / I. Д. Бех, Т. Ф. Алєксєєнко, Г. О. Балл та ін. - Режим доступу: http:// ipv.org.ua/home/39-2010-06-08-18-03-21.html? showall=1.

\section{References (Transliteration):}

1. Buturlim T. I. Formuvannya GendernoYi kulturi starshoklasnikIv u protsesI vivchennya ukraYinskoYi IIteraturi : dis. na zdobuttya nauk. stupenya kand. ped. nauk : spets. 13.00.07 / In-t problem vihovannya NAPN UkraYini. KiYiv, 2013. - $400 \mathrm{~s}$.

2. Programa vihovannya dItey ta uchnIvskoYi molodI v
UkraYinI [Elektronniy resurs] / I. D. Beh, T. F. AlEksEEnko, G. O. Ball ta In. - Rezhim dostupu: http://ipv.org.ua/ home/39-2010-06-08-18-03-21.html? showall=1.

\section{Buturlym Tatyana}

Candidate of pedagogic sciences, teacher of higher category, Nizhyn Region Pedagogical lyceum of Chernihiv Region, Nizhyn (Ukraine)

TERMS AS ATTRIBUTES OF THE SOCIAL-LEGAL FRAMEWORK FOR THE STUDY OF REPLACEMENT CARE FOR CHILDREN UNDER DIFFERENT SOCIAL SYSTEMS

\section{ABSTRACT}

The article determines pedagogical conditions of senior student's gender culture formation while learning Ukrainian literature: motivating students to compare their gender values and artistic character's gender values; improving teacher's professional competence regarding senior student's gender culture formation; use of interactive methods and forms of gender education. Contents of the first pedagogical condition are analyzed: formation the ability to relate literary character's gender culture to their own gender ideology, gender positions, roles, ability to confront gender stereotypes, establish gender dialogic relations; ability to rethink personal gender experience based on awareness of male and female character's gender values; need for gender selfimprovement; ability to design an effective plan of actions towards finding gender harmony etc. It is proved that the result of gender education 
greatly depends on gender competence of the participants of educational process, especially on thoroughness and wholeness of gender knowledge, degree of realization of substance of gender approach, ways of gender theory learning, ability to perform gender text interpretation, ability to dialogic connection between characters' and senior student's picture of the world, student's readiness to transform stereotype gender consciousness or improve their own gender culture, teacher's gender accuracy, considering senior students' psychological peculiarities. It is proved that use of interactive methods and forms of gender education (games, psychological exercises, associative pictures, literature collages, computer presentations using resumptive schemes, tables, graphics, diagrams, group work, pair work, etc.) activate student's cognitive activity, develop creative capacities, accumulate system of gender knowledge, capacities, skills, form high level of gender self-confidence, responsible attitude to possible consequences of their own gender culture production. It is proved that complex realization of above mentioned pedagogical conditions will induce senior students to perception, improving gender culture, realization of gender knowledge, abilities, values in every-day life.

Keywords: gender education, gender culture, Ukrainian literature, gender values, gender competence, interactive psycho-pedagogical exercise.

\section{Бутурлим Татьяна Ивановна}

Кандидат педагогических наук, преподаватель высшей категории, Нежинский областной педагогический лиияей Черниговской области, Нежин (Украина)

\section{ПЕДАГОГИЧЕСКИЕ УСЛОВИЯ ФОРМИ- РОВАНИЯ ГЕНДЕРНОЙ КУЛЬТУРЫ УЧЕНИКОВ 10-11 КЛАССОВ СРЕДСТВАМИ УКРАИНСКОЙ ЛИТЕРА- ТУРЫ}

Аннотация. В статье определены педагогические условия формирования гендерной культуры старшеклассников в процессе изучения украинской литературы: мотивирование учеников к сопоставлению собственных гендерных ценностей и гендерных ценностей художественных персонажей; повышение профессиональной компетентности педагогов относительно формирования гендерной культуры старшеклассников; использование интерактивных методов и форм гендерного воспитания.

Ключевые слова: гендерное воспитание, гендерная культура, украинская литература, гендерные ценности, гендерная компетентность, интерактивные психологопедагогические упражнения. 